\title{
Evaluating the Impact of Boko Haram Terrorism on Yankari Game Reserve as a Tourist Resort in Bauchi State, Nigeria
}

\author{
Dr. Adejoh Apeh Matthew ${ }^{1,}$ Aly Audu Fada ${ }^{2}$ \\ The Federal Polytechnic, Bauchi Department of Hospitality and Tourism Management, School of Science and \\ Technology, Bauchi Nigeria
}

\begin{abstract}
Due to the importance of tourism industry to the global economy, many researchers and practitioners all over the world are making efforts in finding causes of different social conflicts in the world and the effects on tourism and other related industries. This research examined the impact of Boko Haram activities onYankari game reserve in Bauchi State, Nigeria with particular emphasis on accommodation and recreational activities in the reserve. Both secondary and primary data sources were used A survey design was employed. The study used epistemological research and adopted an exploratory approach because it has little information with regards to Yankari game reserve and Boko Haram terroris. The population of the study was the staff of the game reserve and those concerned with accommodations, game viewing and recreational services. The primary data were collected through structured, closed-end questionnaire which has been found convenient by the researchers. In addition interviews were conducted with senior management staff of the game reserve. Descriptive statistics was used to analyze the data. The results indicated that most staff of Yankari game reserve was mindful of the activities of Boko Haram and their impacts on Yankari Game Reserve, noting drastic decline in tourist traffic and room occupancy.Providing job opportunities, beefing up security and public enlightenment on the ills of terrorism on the economy have been recommended as some of the remedies for addressing the problem
\end{abstract}

Key Words: Boko Haram, Terrorism, Tourism, Game reserve

\section{Introduction}

Tourism is one of the industries that generate income and provide employment opportunities. However, it is the most exposed sector to social conflicts compared to other business sectors (Krol, et al, 2000). Tribe (2010) observed that crisis could affect tourism in terms of poor business strategies, employment redundancy, poor infrastructures and damage to properties. This is consistent with Butler ' $\mathrm{s}(1980)$ argument that a number of tourist demands and visitors to a particular destination may decline because of social conflicts

In recent years, Boko Haram terrorist attacks have affected citizens, public properties and business places in Nigeria. This has affected major states in Nigeria especially the northeast areas such as Borno, Yobe, Gombe, Adamawa, Taraba and Bauchi States. These attacks have drastically affected business activities, human and economic developments with major emphasis on the tourism sector. This motivated this study to examine the effect of Boko Haram attacks in the northeast areas particularly on Yankari Game Reserve as a popular tourist destination in Bauchi States, Nigeria..Each year, a large number of tourists, both domestic and international visit the reserve.Whatever hinders tourist flow to Bauchi state will also affect the Game Reserve as a revenue and employment generator for the state.

Boko Haram is a militant Islamist group of people in Nigeria, causing devastations through waves of bombings, massacres, suicides and major destructions of infrastructure (Chothia, 2012).Founded by Mohammed Yusuf in 2002 under the auspices of Jama'atu-Ahlis-Sunna-Lidda- Awati-Wal-Jihad, the group struggles for abolition of Nigeria constitution and upholding of sharia law, pronouncement of Nigeria as an Islamic state and abandoning of western education system (Eme, et al 2012). In 2010, they made their first terrorist attack in Maiduguri, leaving four people dead. They bombed many places in Borno, Yobe, Bauchi, Gombe and Adamawa states in Nigeria. On August 2011, there was suicide bomb attack on the Nigerian police headquarters at Abuja leaving scores of police officers dead. There was another attack on 26th August 2011, at the United Nations Building and over 24 people were killed. Several other attacks were also recorded in cities and towns in northern part of Nigeria such as Suleja, Maiduguri, Damaturu, Kaduna and Jos, in Nigeria ((Eme, et al 2012; Andrew, 2012).

According to Andrew (2012), in Borno and Yobe states, Boko Haram terrorist attacks paralyzed businesses, banking, schools, market, transportation, and hospitality and tourism activities

Shehu (2012) listed the following activities of Boko haram in Northern Nigeria.

i. On 26th J uly 2009, the Boko Haram group clashed with the police and other security agent in Bauchi where 50 members of Boko haram, 2 policemen and 1 soldier were 
killed

ii. On 27th July 2009, Boko Haram attacked divisional police headquarter

Patiskum and 3 officers were killed

iii. On 29th July 2009, there was another attack in Mamudo in Yobe state

iv. On 8th September 2010, Bauchi prison was set on fire and apprehended members of Boko Haram were freed.

v. On 28th January 2011, governorship candidate was killed in Borno state

vi. On 17th June 2011, the First suicide bomb attack was launched at the headquarters of the

Nigerian police in Abuja

vii. On 26th August 2011, The United Nation Building headquarters in Abuja was bombed killing 20 staff.

Any destination with the history of terrorist attacks experiences reduced number of tourists because of fear of attacks (Deemua, et al, 2013). Boko Haram attacks in northern Nigeria led to cancellation of many national and international events in the country. For example, English top-flight club in EPL 2012, and Arsenal proposed 2012 tour to Nigeria were cancelled.

Furthermore, the Nigerian premier leagues; between different clubs in Nigeria also faced similar problems such as the cancellation of football games between Jigawa Golden Star (a Northern club) and Ocean Boys (Eastern base club) (Deemua,et al,2012). The rebellion in northern Nigeria led to the cancellation of international football games between Nigeria super eagles and the Samba boys of Brazil in 2012. These cancellations could have adverse effect onthe tourism industry, because sport tourism contributes significantly to the national economy.

Terrorist attacks have a psychological effect on the tourists and especially those with experiences of previous attacks. For example, many of the attack in Nigeria took place in public places like churches in Bauchi 2011 and 2012, eagles square 2012, the United Nations Building 2012, the Kano Bus terminus explosions 2012 and many banks attacks. This has had a significant effect on the people's experiences. In Bauchi State, roads and major streets were closed and consequently, transportation services, hotels services, restaurants, and some other services were shut down, resulting to serious security and economic hardships for the people.

No matter the reasons claimed for act of terrorism and insurgence, and in whatever form it takes, it could have serious adverse impact on tourism.

\section{Methodology}

This study is an exploratory research aimed at finding out the effects of Boko Haram attacks on patronage by both domestic and international tourist on Yankari Game Reserve as an eco-tourist resort in Bauchi State, Nigeria. A survey design was employed in conducting this study as it required the opinion of individuals involved in handling customer service such as accommodation, recreational services and information services. This approach follows the opinion of Kumar (2005) who suggested that survey is an adequate instrument for exploratory study.

Structured, close-ended questionnaire was used for obtaining the primary data .The choice of questionnaire was to allow the respondents to respond at their convenient time.The questionnaire was divided into three sections, A to C. Section A allowed the respondent to provide background information such as department, length of service, status and general awareness about the activities of Boko Haram; Section B contained questions which provide data about the effect of Boko Haram on room occupancy; and Section C contained questions whose answers provide information on the effect of Boko Haram activities on visitors inflow for game viewing In addition, interviews were conducted with three senior management staff of Yankari Game Reserve . Also depending on responses received, probing questions were asked to obtain additional information and some questions were rephrased or repeated to get clearer responses.

Interview responses were recorded on tapes and were later transcribed, organised into patterns

and descriptive units and this was related to existing theories for interpretations

The population of the study comprised the 110 members of staff of the Yankari Games Reserve who provides services such as accommodation, game viewing and recreational services to tourists and regular patrons. The study adopted a combination of inductive and deductive qualitative analysis. Snedecor and Cochran's (1989) descriptive model of frequency distribution and mean deviation were performed to determine the relationship between outcome and observation.

\section{Results and Discussions}

In an attempt to find out whether the Yankari Game Reserve staffs were aware of the existence of Boko Haram terrorism, questions were asked and analyses presented. The results indicate that 46 respondents $(57.5 \%)$ agreed that they were aware of the activities of Boko Haram in Nigeria. while 25 respondents $(31.5 \%)$ were very much aware of the situation. This implies that the staffs of Yankari Game Reserve are strongly aware of the social conflict going on and its likelihood of affecting their services (See Table 1). In addition, 71 
respondents (88.75\%) acknowledged the appearances of Boko Haram activities in Bauchi state, the domain of the Yankari Reserve (Table 2)

Over 50\% of the staff of Yankari Game Reserve agreed on bombing of worship places, attack on police posts and silent killing of unsuspected individuals as evidence of Boko Haram activities in Bauchi state (Table 3). The invasion of Bauchi state by the Islamic fundamentalists have had negative effects on the tourism activities in Bauchi State. Many people suffer psychological trauma and this will prevent individuals from visiting the Yankari Game Reserve which will eventually affect the future of tourism industry in the state.

A continued drop in the number of tourists to Bauchi, accompanied by low room occupancy and polarized tourism related services, makes Boko Haram terrorism a threat to the survival of Yankari Game Reserve in particular and the Nigerian tourism industry in general.(See Table 4)

This result corresponds with the interview granted by one of the respondents in which he said;

"For us at this end, business has been epileptic as customers keep away leading to

drop in occupancies. Our average room occupancy these days is between 10 and $15 \%$ which is considered worst ever".

This explains the reasons why economists criticize social conflicts as unhealthy for economic development in many developing countries. For example, Abdullahi (2011) describes the Egypt 1994 terrorist attacks as a blow to the Egyptian economy, most especially the tourism industry.Fig 1 shows a picture of the trend of room occupancy during the Boko Haram regime. This condition is supported by evidence of decline in tourist flow to Yankari Game Reserve between 2010 and now when the fear of Boko Haram terrorism has been high (See fig 2) A total of 41 respondents $(51.25 \%)$ agreed there were cases of cancelled visits by tourists to Yankari Game Reserve (Table 5). The interview with the tourism officer substantiates the fact that tourists cancelled bookings. He stated

....there is a lot of cancellation of bookings or reservation particularly from Lagos,

Port Harcourt, and Abuja because the location of Yankari game reserve happens to be in

the northeast and the visitors are afraid of coming to Yankari because of prevailing

insecurity, especially those who are using flight from Lagos to Abuja or from Lagos to

Kano. The activities of Boko haram terrify people:

The years 2011 and 2012 recorded a high number of cancelled bookings by tourists to the reserve due to the activities associated with the fear of Boko Haram in Bauchi State.Deemua et al (2013) observed that Boko haram attacks in the Northern Nigeria have led to cancellation and reduction in many National and International events in Nigeria.The finding has indicated minimal use of recreational facilities at Yankari Game Reserve. This supports Suleiman (2012) in Eme, et al (2012) who observes that tourism business has declined as a result of Boko Haram terrorism.

\section{Conclusion}

This study established the evidences of Boko Haram attacks in Bauchi state of Nigeria by bombings of worship places, attacks on polices stations and silent killing of people . It was also established that Boko Haram attacks have affected the social lives of people where people fear to move around to participate in any worthwhile activity. There have been drastic drops in room occupancies and use of other amenities at the reserve occasioned by decline in the number of tourist flow to Bauchi as a result of threat to life and property. The implication of this development is the inevitability of setback in promotion of Yankari as a game resort and Bauchi State tourism industry as a whole.

This study recommends that the Bauchi state government and the federal government should create more jobs and skill acquisition programs in order to keep the youth engaged and reduce the poverty level.

The study also recommends that Bauchi state government of Nigeria should improve the educational sector and implements strategies to reduce the level of illiteracy among many people in the state.

In conclusion, the managers in Yankari Game Reserve should formulate and implement new strategies that would attract tourists to Yankari Game Reserve. For example, by carrying market campaigns, advertising, and promotions such as price reductions and discounts

\section{References}

[1]. Abdullahaii, M.D., and Abdulrazak, C. (2011) 'Political Instability Country Image for Tourism in Bangladesh', Proceeding of International Conference of Social Science, economics and Art. University of Uttora Malaysia

[2]. Andrew, W. (2012)'Special Report,' The United State, Institute of Peace .Washington, Dc 20037.WWW.US.p.org.

[3]. Butler, R.W. (1980) The concept of the tourist area life-cycle of evolution: implications for management of resources. Canadian Geographer 24 (1), 5-12

[4]. Chothia,F.(2012). Who are Nigerians Boko Haram Islamists? Available at

[5]. http://www.bbc.co.uk/news/world-africa-13809501 accessed on (01/09/2013)

[6]. Deemua, G.A., Ogujiofor, M.A. (2013) 'Terrorism in Northern Nigeria: Effects on Sports Development,' Academic Research International, vol.4 (2) pp293-296. 
[7]. Eme, O.K. And Ibietan.J.(2012) 'The cost of Boko Haram Activities in Nigeria'.ArabianJournal, of business and management, vol.2 (2).

[8]. Krol, J Anderson,J.,Boudoin,P.andPouchanic.S.(2000)International Tourism Report.University of MAsschuttess-Darntmouth.

[9]. Kumar, Ranjit, 2005, Research Methodology-A Step-by-Step Guide forBeginners,(2nd.ed.),Singapore, Pearson Education.

[10]. Shehu, A.B (2012) Ethno-Religious, Conflicts/sViolencein Northern Nigeria.Master Thesis University of Wien.

[11]. Snedecor, George W. and Cochran, William, G. (1989) Statistical Methods, Eighth Edition, Iowa State University Press.

[12]. Tribe, J. (2010) Strategy for Tourism .Oxford: Good fellow Publishers Limited

Table 1: Awareness about Boko Haram Activities

\begin{tabular}{|l|l|l|l|l|l|l|l|l|}
\hline & House keeping & & Game Safari & & Recreation & \multicolumn{2}{l|}{ Total } & \\
\cline { 2 - 10 } & Responses & $\%$ & Responses & $\%$ & Responses & $\%$ & Responses & $\%$ \\
\hline (a) I am aware & 14 & 17.5 & 22 & 27.5 & 10 & 12.5 & 46 & 57.5 \\
\hline (b) I am not aware & 0 & 0 & 9 & 11.25 & 0 & 0 & 9 & 11.25 \\
\hline $\begin{array}{l}\text { (c) I am very much } \\
\text { aware }\end{array}$ & 0 & 0 & 25 & 31.25 & 0 & 0 & 25 & 31.25 \\
\hline $\begin{array}{l}\text { (d) I have never } \\
\text { heard of Boko } \\
\text { Haram }\end{array}$ & 0 & & & & & & & \\
\hline Total & & & 0 & 0 & 0 & 0 & 0 & 0 \\
\hline
\end{tabular}

Source: Field Survey. 2013

Table 2: Appearances of Boko Haram Activities in Bauchi

\begin{tabular}{|l|l|l|l|l|l|l|l|l|}
\hline & House keeping & & Game Safari & & Recreation & & Total & \\
\hline & Responses & $\%$ & Responses & $\%$ & Responses & $\%$ & Responses & $\%$ \\
\hline $\begin{array}{l}\text { (a) Yes, } \\
\text { there are }\end{array}$ & 12 & 15 & 49 & 61.25 & 10 & 12.5 & 71 & 88.75 \\
\hline $\begin{array}{l}\text { (b) No, there } \\
\text { are not }\end{array}$ & 0 & 0 & 1 & 1.25 & 0 & 0 & 1 & 1.25 \\
\hline (c) Not sure & 14 & 17.5 & 56 & 70 & 10 & 12.55 & 80 & 100 \\
\hline
\end{tabular}

Source: Field Survey. 2013

Table 3: Evidence of Boko Haram Activities in Bauchi

\begin{tabular}{|c|c|c|c|c|c|c|c|c|}
\hline & House keeping & & Game safari & & Recreation & & Total & \\
\hline & Responses & $\%$ & Responses & $\%$ & Responses & $\%$ & Responses & $\%$ \\
\hline $\begin{array}{l}\text { (a) Bombing } \\
\text { worship places }\end{array}$ & 1 & 6.25 & 30 & 37.5 & 7 & 8.75 & 42 & 52.5 \\
\hline $\begin{array}{l}\text { (b) Attacks on police } \\
\text { posts }\end{array}$ & 3 & 3.75 & 10 & 12.5 & 3 & 3.75 & 16 & 20 \\
\hline $\begin{array}{l}\text { (c) Attacks on major } \\
\text { business areas and } \\
\text { markets in some } \\
\text { location }\end{array}$ & 1 & 1.25 & 3 & 3.75 & 0 & 0 & 4 & 5 \\
\hline $\begin{array}{ll}\text { (d) } & \text { Burning } \\
\text { residential building }\end{array}$ & 0 & 0 & 0 & 0 & 0 & 0 & 0 & 0 \\
\hline $\begin{array}{l}\text { (e) Silent killing of } \\
\text { unsuspecting citizens }\end{array}$ & 3 & 3.75 & 10 & 12.5 & 0 & 0 & 13 & 16.25 \\
\hline (f) Attacks on banks & 2 & 2.5 & 3 & 3.75 & 0 & 0 & 5 & 6.25 \\
\hline Total & 14 & 17.5 & 56 & 70 & 10 & 12.5 & 80 & 100 \\
\hline
\end{tabular}

Source: Field Survey, 2013

Table 4: Evidence of Attack by Boko Haram on Hotels and Tourist attractions

\begin{tabular}{|c|c|c|c|c|c|c|c|c|}
\hline & House keeping & & Game Safari & & Recreation & & Total & \\
\hline & Responses & $\%$ & Responses & $\%$ & Responses & $\%$ & Responses & $\%$ \\
\hline (a) Yes & 8 & 10 & 0 & 0 & 0 & 0 & 8 & 10 \\
\hline (b) No & 2 & 2.5 & 53 & 66.25 & 8 & 10 & 63 & 78.75 \\
\hline (c) Not sure & 4 & 5 & 3 & 3.75 & 2 & 2.5 & 9 & 11.25 \\
\hline Total & 14 & $\mathbf{1 7 . 5}$ & 56 & 70 & 10 & 12.5 & 80 & 100 \\
\hline
\end{tabular}

Source: Field Survey, 2013

Table 5: Numbers of Visitors to Yankari Game Reserve

\begin{tabular}{|c|c|c|}
\hline & Response & $\%$ \\
\hline (a) There has only been insignificant drop in number of tourists to Yankari Game Reserve & 24 & 30 \\
\hline (b) There have been consistent flow of tourists to Yankari Game Reserve & 0 & 0 \\
\hline (c) Tourist flow to the Reserve has been on the increase in recent times & 0 & 0 \\
\hline Total & 80 & 100 \\
\hline
\end{tabular}




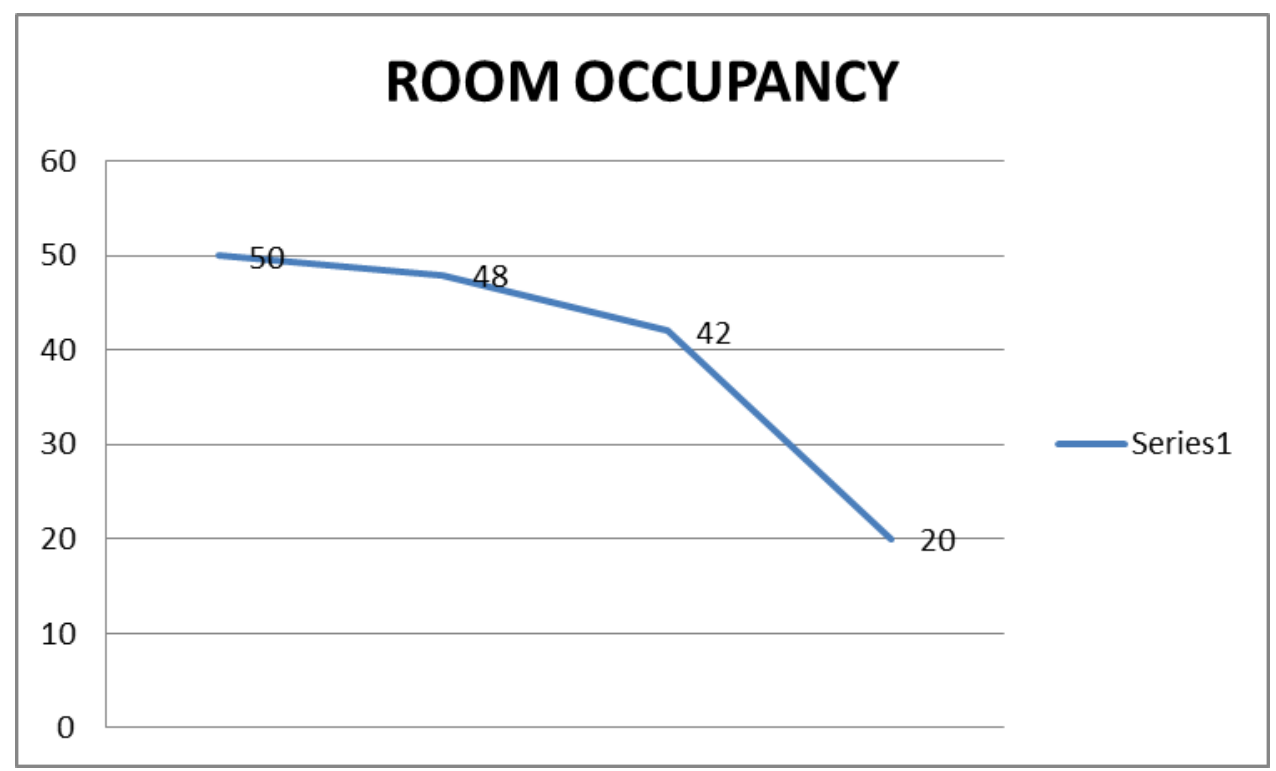

Fig 1:

TOURIST FLOWS TO YANKARI GAME RESERVE

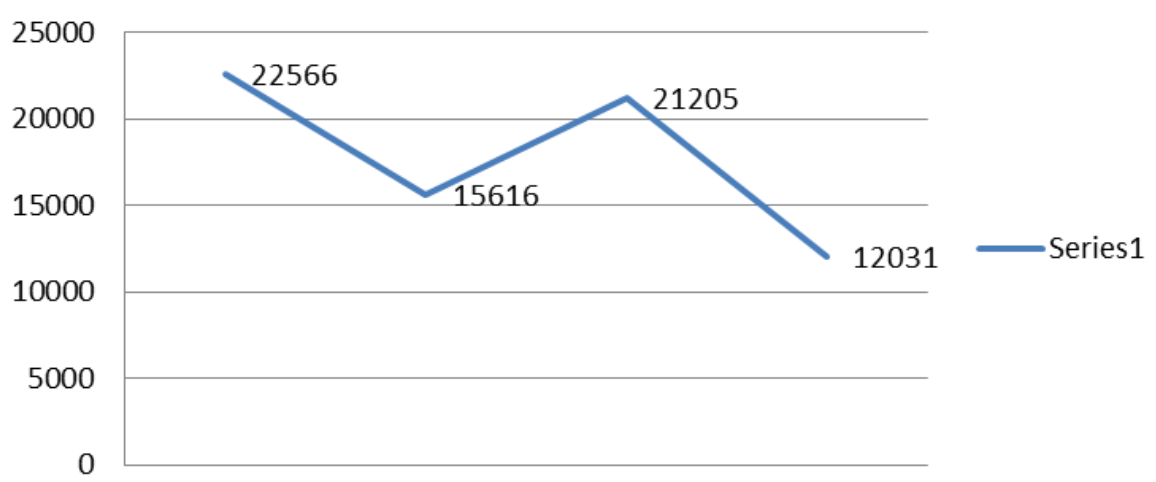

Fig 2 